\title{
Hamlet's prophetic soul: an obscured myth?
}

\section{Werner Habicht}

\section{(2) OpenEdition}

\section{Journals}

Electronic version

URL: http://journals.openedition.org/shakespeare/497

DOI: $10.4000 /$ shakespeare.497

ISSN: 2271-6424

\section{Publisher}

Société Française Shakespeare

\section{Printed version}

Date of publication: 1 November 1984

Number of pages: 113-126

\section{Electronic reference}

Werner Habicht, " Hamlet's prophetic soul: an obscured myth? », Actes des congrès de la Société française Shakespeare [Online], 5 | 1984, Online since 01 January 2007, connection on 30 April 2019. URL : http://journals.openedition.org/shakespeare/497 ; DOI : 10.4000/shakespeare.497 
SOCIETE FRANÇAISE SHAKESPEARE

Actes du Congrès 1983

\section{MYTHE ET HISTOIRE}

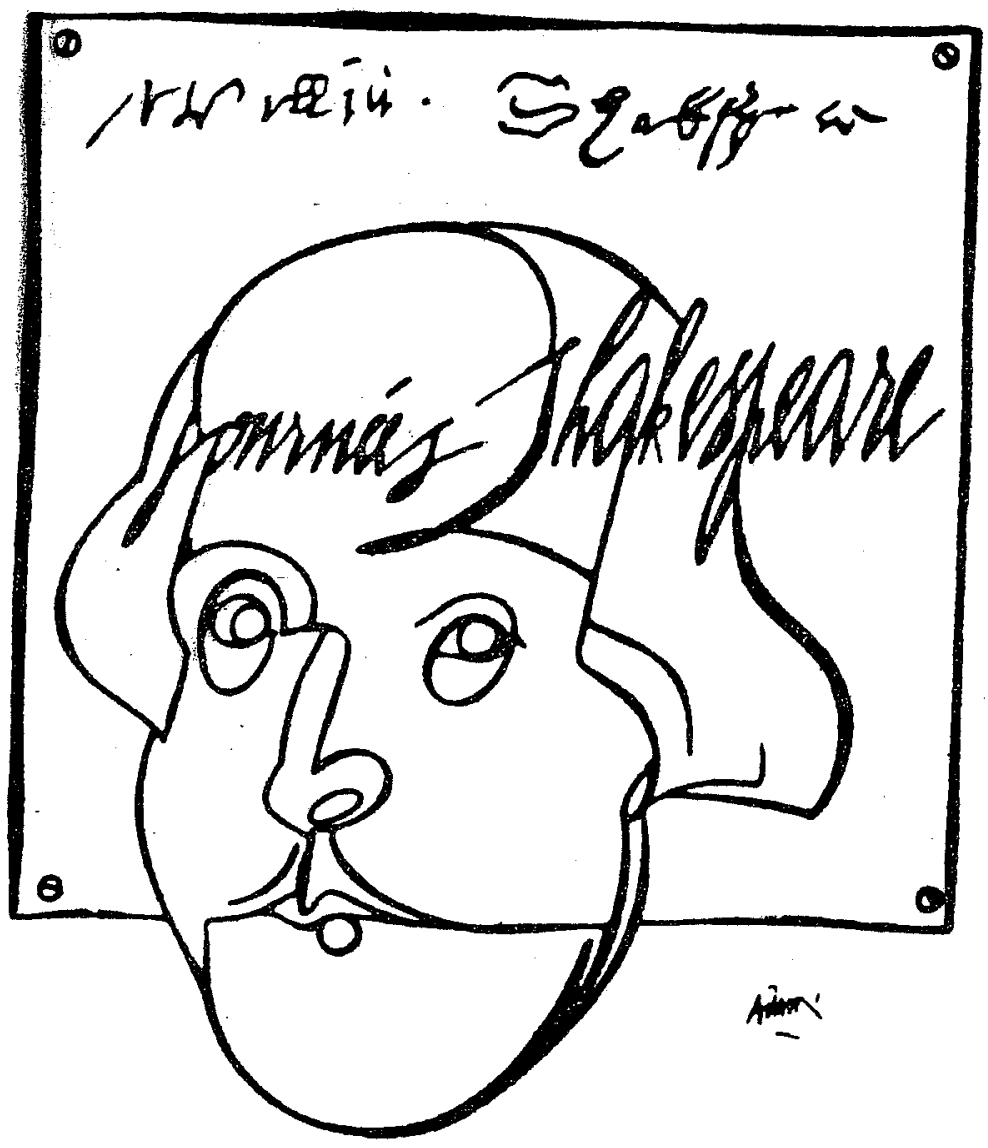

$$
\begin{array}{r}
\text { DiReCteur DE LA' PUblicatic } \\
\text { M.T. Jones-Davie }
\end{array}
$$

Publié avec le concours du Centre National de la Recherche Scientifiq

$$
\text { JEAN TOUZOT Libraire - Editeur }
$$

38, rue Saint-Sulpice 75278 PARIS CEDEX 06199 


\section{HAMLET'S PROPHETIC SOUL : AN OBSCURED MYTH ?}

These remarks, without pretending to contribute to the big issues of myth theory, can at best hope to offer a modest marginal note on some (possibly mythical) implications of the very words from Hamlet quoted quite unsymbolically in the title. With these words Prince Hamlet reacts to the revelation by the ghost of the King his father that the latter was murdered by the King his uncle. They are indeed dramatically significant, since the ghost's revelation constitutes a crucial point in the exposition. It sets the dramatic action in motion, and Hamlet's emotional apostrophe elicited by it -

O my prophetic soul! (I.v.41).

- marks the beginning of the play's complications, and is also a manifestation of Hamlet's sensitive character. The meaning of these words, like that of many familiar Shakespeare quotations, is usually taken for granted, especially since on the surface it appears to be obvious enough. « $\mathrm{O}$ my prophetic soul »: Hamlet seems to be saying : «I thought as much; I have had a suspicion confirmed $»$. Hamlet may at this point be specifically referring to his previous misgivings about Claudius, the $《$ smiling villain» ${ }^{1}$; but in doing so he surely displays only one symptom of a more general awareness of hidden evil, of the «corrupted currents of this world», an awareness which works absorbingly within him, though it is repressed by the social mechanisms and expectations of the court of Denmark, which is his «prison». I shall not attempt the psychoanalytical exploration which his condition invites, and which would in any case have to remain somewhat speculative.

Instead I propose, in a perhaps more conventional empirical approach, to redirect a moment's attention to 
some of the source material behind Shakespeare's tragedy. For if we remember earlier versions of the Hamlet story, the mythical image of a prophet hero can ultimately be fathomed. What I should like to suggest is, first, how that image in the process of its incorporation into pseudo-history and history was transmitted and obscured; and, secondly, how its function was revitalized, and translated into dramatic terms, within the Shakespearean context.

A clue to Hamlet's «prophetic soul» is readily available in the earliest literary version of the story, though of course not at the same point as in Shakespeare's play. In Saxo Grammaticus's $12^{\text {th }}$ century Gesta Danorum there is, after all, no ghost to react to, as none was needed either to reveal to Amleth the facts about the regicide (which were public knowledge) or to inspire him with revenge (which would have been the usual thing to be expected from the Teutonic son of the victim). Nor do Hamlet's subsequent delay and madness, which are so disconcerting in Shakespeare, present a problem in Saxo's account, in which both have crystalclear motivations in being part of Amleth's revenge strategy. Instead, the «prophetic soul» of the original Amleth manifests itself sensationally in a later stage of the story in the England episode, which in Shakespeare's tragedy is drastically cut short. Saxo's Amleth, shipped off by the the ursurper Feng, does arrive in England with his two companions bearing the dangerous letter which he is able to twist in his favour. The King of England welcomes him with a splendid feast, in the course of which, however, Amleth comports himself somewhat offensively : he refuses the food and drink with ostentatious disgust and makes sneering remarks on his royal hosts. When afterwards in the bedroom his companions question him about his unmannerly behaviour, he explains :

that the bread was flecked with blood and tainted; that there was a tang of iron in the liquor; while the meats of the feast reeked of the stench of a human carcase, and were infected by a kind of 
smack of the odour of the charnel. He further said that the king had the eyes of a slave, and the queen had in three ways shown the behaviour of a bondmaid $^{2}$.

This utterance causes the royal host, to whom it is retailed by an eavesdropping spy, to investigate the matter. The results are macabre, but substantiate Amleth's gift of prophecy. The bread, though baked by the king's baker, turns out to have been made with flour from grain that had grown near a field covered with the ancient bones of slaughtered men; the pork was from hogs which had once battened on the rotting corpse of a robber; and the mead had been brewed with water from a well beneath which some rusty swords were discovered. Amleth's comments on the king's and the queen's countenances also entail embarrassing discoveries : that the king is in fact a bastard, offspring of his mother's hushed-up adultery with a slave, and that the mother of the queen had indeed once been a bondmaid.

Shakespeare may have discarded this section of the story as being too unrelated to his dramatic purpose, or as smacking too much of the fairy tale. It is perhaps for this reason that Shakespeare critics have paid less attention to it than have folklorists. From these we can learn that it represents a widespread type of fairy tale dealing with extraordinary powers of perception and deduction (as the great indexers of folklore motifs have labelled $\mathrm{it}^{3}$ ), a type that can be traced throughout Europe, Africa, and particularly the Far and Middle East, though its ultimate origin whether from India or Arabia - remains unclear ${ }^{4}$. Th is fairy tale type also occurs in Denmark (in Jutland, the country of Saxo Grammaticus) in the form of the tale of the Three Clever Students ${ }^{5}$. In this tale three poor students are given shelter and dinner by a rich gentleman. At table one of them refuses to eat the meat, the second abstains from drinking the wine, and the third refrains from joining in a toast to their host. Afterwards in the bedchamber they explain their behaviour to one another. The meat had tasted of dog, 
says one student; the wine had tasted of drowned children, declares the second, and the toast had been refused to a bastard, maintains the third. Again, their conversation is eavesdropped upon by the master of the house, who at once makes enquiries into what he has heard. From the crying cook he learns that she had in fact replaced the burnt pork by a hastily slaughtered dog; examining the wine barrel he finds the dead body of a naked child at its bottom; and from his mother he wrests the confession that a cattle-drover had been his illegitimate father. His discoveries fill him with respect for the sagacity of the three students, whom he dismisses with twenty ducats each.

In this Danish fairy-tale, then, as in numerous variants of the same type attested in different parts of the world, we meet the very same motifs, the same two kinds of exceptional perception as displayed by Saxo Grammaticus's Amleth : perception of hidden truths by taste, and perception of a person's bastardy. Fairy tale material of this kind ultimately originating in the Far or Middle East may have reached the North via Scandinavian trade connections with Byzantium, and it probably accrued to the Amlethsaga in a pre-literary stage ${ }^{6}$. In Saxo's Gesta Danorum these demonstrations of extraordinary perception are already integrated into the structure of the narrative. Their performance by Amleth in the England episode links up with, and brings to a climax, his riddling displays of feigned madness meant to camouflage his purpose of revenge; and they also initiate further action : impressed by Amleth's gifts of perception, the English king offers him his daughter, whom Amleth condescendingly accepts as his wife, which is the starting point of his further adventures.

Also, Saxo in his England episode has arranged the folklore material so as to make Amleth the heroic centre of interest. Whereas in most fairy tale analogues (as, for instance, in the Danish one mentioned) the various displays of perception are evenly distributed among several characters - three brothers, friends, or, indeed, students -, in Saxo's narrative they are all performed by Amleth 
alone, despite the presence of his two anonymous companions, the prototypes of Rosencrantz and Guildenstem,whose parts are a mere foil against which Amleth's singularity as a prophet hero shines all the more brightly ${ }^{7}$.

There is, moreover, a remarkable consistency in Saxo's combination of the five examples by which Amleth exhibits what appear to be supernatural abilities. No such consistency prevails in the divers fairy tale analogues and their motif complexes. In these the protagonists' displays of extraordinary perception are often given perfectly rational and realistic explanations, based as they are on a keen feel for natural phenomena. Many tales establish this clearly at the very outset, particularly Middle Eastern ones, which have a tendency to begin with a camel test : the fairy tale characters can give a precise description of a camel, including its riders and load, although they have never seen it; for they are able to recognize and interpret the traces it has left behind it. Other «tests» often incorporated in the popular tales also depend on deductions from concrete observation: jewel tests, for instance, whereby an expert touch distinguishes genuine jewels from false ones; or horse tests, where the hero's examination of the horses' teeth exposes crooked horse dealers; or also bed tests, where (as in the tale of the Princess and the Pea) hypersensitivity reacts through many mattresses to minimal foreign bodies ${ }^{8}$. By contrast, Saxo's pseudo-historical saga has a more irrational effect, because Amleth's feats of perception by taste are linked up not with such demonstrations of «natural» skills, but with his riddling behaviour and his feigned madness. Even his perception by taste appears to be less «natural». When in fairy tales a taste of dog is diagnosed in the meat and it turns out on enquiry that either dog meat was in fact served up or that the slaughtered pig had once been suckled by a bitch ${ }^{9}$, it is then explained how the deductions have been arrived at - for instance from the fact that the meat becomes lumpy when chewed (as in a Turkish tale), or that its fibres betray its canine origin (as in a variant from Tunesia), or that 
it is not filling (as in a German example) ${ }^{10}$. No such explanations are given in Saxo, where, moreover, Amleth detects even the king's bastardy without referring to the behavioral symptoms of illegitimate birth usually mentioned in the tales, except for a brief remark on the king's «serviles oculi». Only in the very last - not, as in the typical tale, in the first - of his displays of perception are Amleth's comments on the humble origin of the English queen substantiated by more tangible clues - the way she fidgets with her dress and picks her teeth -, so that Amleth's powers of perception, which on the whole and primarily seem to be a supernatural gift, are in an afterthought as it were given a slightly more realistic touch.

At the same time the discoveries precipitated by Amleth are in Saxo's treatment given some local and historical colouring, which again stands in contrast to most tales. The wheat field from which the bread that tasted of blood ultimately came is near a ground «bearing all the signs of ancient carnage» ( adhuc manifesta antiquae stragis vestigia») ; the rotting corpse of a robber eaten by the hogs, and the rusty swords at the bottom of the well, betrayed by the meat and the drink respectively, appear to allude to events of yore; and the king's bastardy and the blemish in his queen's pedigree are of course pointers to embarrassing incidents in the history of the royal family. It is true that individual fairy tale parallels can also be found for some of these special features of Saxo's narrative - the concentration of several extraordinary perception motifs on one character, the lack of «natural» evidence, the interest in the past. But their cumulative effect in the Amleth saga suggests a protagonist who has a supernatural and, indeed, prophetic gift of evoking things hidden in a forgotten past.

Shakespeare, of course, may never have known Saxo Grammaticus's Historia Danorum directly. But - and this is more important in our context - he doubtless did have access to François de Belleforest's Histoires Tragiques, in which the Amleth story is adapted so as to conform with the expectations of sixteenth-century readers, and it is 
here that darkness descends upon the mythical hero. Belleforest dwells at considerable length on the England episode and on Amleth's power of perception, and he adds a good deal of moralizing comment. He lays particular stress both upon the supernatural quality of Amleth's gift and upon the fact that it has to do with the past. He expressly describes him as a diviner, a soothsayer, and he compares him with no less than the prophet Merlin. In his comments he adduces the orthodox doctrine of magic as contained in numerous sixteenth-century treatises from Jean Bodin to King James, according to which black magic associated with the devil included such things as soothsaying, divination, even water divining. By describing Amleth as a diviner, Belleforest thus transfers him into a demonic sphere, though not without patronizingly making allowances for the archaic, pagan and northern world he lived in; for

veu qu'en ce temps là tous ces pays Septentrionaux, estans sous l'obeissance de Sathan, il y avait une infinité d'enchanteurs : et n'estoit fils de bonne mere, qui n'en sçavoit assez pour sa provision, si comme encor en la Gothie et Biarmie, il se trouve infinité qui sçavent plus de choses que la sainteté de la religion Chrestienne ne permet (. . .) Et ainsi Amleth, vivant son père, avoit esté endoctriné en celle science, avec laquelle le malin esprit abuse les hommes et advertissoit ce prince (comme il peut) des choses ja passees. ${ }^{11}$

Belleforest moreover explains Amleth's divinatory powers in psychological terms equally orthodox from a sixteenth-century point of view; he attributes them to «la vehemence de la melancholie» as observed in those who are «influés de Saturne», and who in their trance-like moments of «fureur» utter things beyond the reach of normal understanding $^{12}$. 
Belleforest also points out expressly that Amleth's prophecies concern things past, though this makes them no less diabolic. Accordingly the things past revealed by Amleth are given still more «historical» colouring in Belleforest's narrative than they already had in Saxo's account. The bonestudded ground near the wheat field is now an actual ancient battle site; the anonymous robber is now a concrete «larron justicié pour ses forfaits et demerites»; and to the rusty swords below the bottom of the well rusty armour is added, which suggests an ancient outlaw hideout. Significantly, too, Belleforest stresses the supernatural nature of Amleth's sensitiveness, by omitting, in the last deduction concerning the queen, the «natural» and realistic clues which even Saxo had mentioned ${ }^{13}$. Thus the sixteenth-century Amleth has become a magician capable of demonically conjuring up evils buried in the past.

Shakespeare somehow seems to be continuing from here when he has Hamlet acknowledge his «prophetic soul», even though he abandoned the England episode and its fairy tale elements. Shakespeare himself often associates the very words «prophet» or «prophetic» with magic. They may refer, as in Troilus and Cressida, to the trance of Priamus, who is «like a prophet suddenly enrapt» (V.3. 65 ) or, as in Othello, to that of the Sibyll when manufacturing the magic and fateful handkerchief - she «in her prophetic fury sew'd the work» (III. 4. 72), not to mention the «prophetic greeting» with which the witches in Macbeth meet the hero. And wherever the entire expression «o my prophetic soul» occurs elsewhere in Elizabethan drama, supernatural knowledge is involved, as, for example, in John Fletcher's The Double Marriage, where a duke uses the phrase when realizing that an ominous dream of his has come true, or in Philip Massinger's The Emperor of the East, where a fullfledged magician appeals to «my prophetic soul $»^{14}$. And in Shakespeare's own sonnet 107 «the prophetic soul /Of the wide world» is parallelled with «the sad augurs» who «mock their own presage» to be 
contrasted with the poetic monument eternalizing love.

The magical and demonic dimension of the «prophetic soul» of Shakespeare's Hamlet, too, is indicated - by the supernatural context of the ghost scene in which it is now verbalized. The Shakespearean ghost, probably incorporated into the story at the Urhamlet stage, is of course a by then conventional Senecan device. And yet Shakespeare not only uses, but also questions the literary ghost convention by appealing to beliefs current among his audience. Hence his ghost is an ambivalent «thing》. Significantly, the ghost elicits Hamlet's acknowledgement of his «prophetic soul» by describing the murder with suggestions of the serpent in the garden (evoking the devil in paradise) : «the serpent that did sting thy father's life/now wears his crown», and he then goes on to identify the «snake» Claudius as a practitioner of witchcraft, not without also alluding to his incestuous adultery. (reminiscent of the bastardy motif of the sources) :

Ay, that incestuous, that adulterate beast

With witchcraft of his wit, with traitorous gifts-, $O$ wicked wit and gifts, that have the power

So to seduce! - won his shameful lust

$$
\text { (I.v. 43-46) }
$$

Although the images of devil and witch are projected onto Claudius, they also seem to affect the projectors. The ghost «may be a devil» as well as an «honest ghost». And since it is as it were the objective correlative of Hamlet's «prophetic soul», the stirring of the latter is no less ambivalent. Moreover the ghost, though initially introduced as an objective reality, then infiltrates into Hamlet's subconscious; for after his dialogue with Hamlet the ghost is only perceived by. Hamlet himself, both in the ensuing oath scene and later in the closet scene. Hence the possibility of a demonic element in Hamlet's «prophetic soul» as well as in the ghost must be reckoned with, even though what is revealed proves to be the historical truth. As Belleforest had pointed out, the devil plays a part in the divination of things past. 
Concealed things past, however, are what Shakespeare's tragedy is about. Here neither the regicide nor the identity of its perpetrator are (as in Saxo and in Belleforest) public knowledge, but have been covered up in a world that has a general tendency to hide its rotten foundations behind a splendid facade of court ceremony, successful politics, unctuous sermonizing and hypocritical prayers. And yet the process by which in the course of the play the historical crime is exposed and made to catch up with the present follows the fairy-tale pattern mapped out in the displays of extraordinary perception of the saga Amleth, though the pattern is now subverted and entangled - precisely because Hamlet's "prophetic soul» is now deheroicized, made ambiguous and obscured, and because the splendid and corrupt state of Denmark and the social roleplaying that goes on in it resist exposure. But the main elements of that pattern stand out clearly. There is, first, Prince Hamlet's brusque behaviour as soon as he appears on the stage in I. ii (even before meeting the ghost), in which he, like Saxo's Amleth at the English banquet, outrageously ignores the pertinent protocol and reacts sensitively to what merely «seems». He does sense hidden truths of the past, though they are now harder to uncover. Se condly there is as in the tales and in the saga - the eavesdropping upon him by the king and his spies, though in Shakespeare the efforts of these, first of Polonius, then of Rosencrantz and Guildenstern, are in vain and have to be be paid for with their lives. And there are, thirdly, the enquiries set off by Hamlet's cryptic behaviour and utterances, and the tangible confirmation of the truth these enquiries eventually yield. They were readily undertaken by the saga king, but in Shakespeare are allocated to two Kings who are less trustworthy. Confirmation is provided by the murdered King Hamlet; but he is a ghost and therefore a suspect witness, whose evidence is unacceptable in the real world. En quiries are made by King Claudius, but he is the murderer himself, who is interested in concealing, not in revealing, the historical truth. 
Since the extraordinary perception pattern is thus integrated in Shakespeare's tragedy as a whole, the England episode that originally contained it is no longer needed. The latter presumably had already lost much of its function in the Urhamlet. In the German play Der bestrafte Brudermord, which may be derived from the Urhamlet, the England episode is reduced to a grotesquely comical scene, in which Hamlet merely saves his threatened life with cunning, but by no means supernaturally. Shakespeare has abbreviated it even more radically by introducing the pirates, who prevent Hamlet from even getting as far as England. And in any case the England episode had lost its original function of connecting different elements of the plot - the revenge story and Hamlet's future adventures arising out of his union with the English princess; for in the play, unlike in the saga, Hamlet perishes in the act of revenge.

In short, Hamlet's «prophetic soul», his divination of evils hidden in the past, which in the saga was sensationally demonstrated at the English feast, has in Shakespeare's tragedy been directed towards a more important and more absorbing object : the Danish regicide itself, which has undermined the seemingly ordered state that has covered it up, and which has now become the past that precedes the dramatic action. Entrapped in both the ambivalence of the supernatural and the morbidity of state and society, the prophet nature of Shakespeare's Prince Hamlet is perverted into an «antic disposition», a mask of madness, the role of a jester. Whereas in the saga Amleth's demonstrations of his divinatory gift were the final confirmation and the climax of his feats of riddling madness cleverly feigned for the sake of an unquestioned revenge principle, in Shakespeare, conversely, the revenge principle is questioned, and the stirring of Hamlet's «prophetic soul» is the cue that will cause him to assume the mask of mad and incongruous behaviour in which the real corruption and the unexorcised past of the seemingly splendid world around him is grotesquely reflected. 
Hence, Hamlet's gift of prophecy becomes part of his role as a jester. In II.ii , after Rosencrantz and Guildenstern have told Hamlet (who at first had «conjured» them; cf. 283) about the arrival of the players at the castle, he has, as Polonius approaches in order to inform him officially, no difficulty in proclaiming :

I will prophesy he comes to tell me of the players, mark it. (382).

And this mock prophecy is of course immediately confirmed by Polonius's verbose announcement prompted by Hamlet's cue. Just as in Sonnet 107 (the «prophetic soul» sonnet already mentioned) «the sad augurs mock their own presage», Hamlet thus parodies his own «prophetic soul». And just as in that sonnet the art of prophecy is set off against, and superseded by, the superior art of poetry, so Hamlet's debunked prophecising is then superseded by the art of the players who are thus introduced. It is their mousetrap performance that will reveal the truth about the murder. In the complex and out-of-joint world depicted by Shakespeare the old myth of the prophet hero, which still glimmers through in Hamlet's spontaneous exclamation «O my prophetic soul» elicited by the ghost, has become devalued and obscured. But its function in revealing the truth of the past is alloted to the actors, about whose art Hamlet has judicious things to say without being able to emulate it (cf. II. ii. 545 ff.). Hamlet himself reflects upon the transfer of function:

The spirit that I have seen May be a devil, and the devil hath power T'assume a 'pleasing shape, yea, and perhaps Out of my weakness and my melancholy, As he is very potent with such spirits, Abused me to damn me. I'll have grounds More relative than this. The play's the thing Wherein I'll catch the conscience of the King. 
In the last analysis, then, Shakespeare's treatment of Hamlet's prophetic soul would seem to reflect how the man of the theatre understands his role as an artist. In an age in which the prophet's powers of perception and divination are considered with suspicion and are, moreover, treated as symptoms of weakness and melancholy, it has become the task of the theatre to confront the real world with myths that mirror the hidden truth. 


\section{NOTES}

1. This is pointed out by H. Jenkins in his (New) Arden Edition of the play (London, 1982), p. 218. All Hamlet quotations are from this edition.

2. Saxo Grammaticus, Gesta Danorum, ed. A. Holder (Strassburg, 1886), lib. 3, p. 93 : «In terrogatus igitur a sociis Amlethus, quid ita hesternis epulis, perinde ac venenis abstinuisset, panem cruoris contagio respersum, pocioni ferri saporem inesse, carneas dapes humani cadaveris oliditate perfusas ac veluti quadam funebris nidoris affinitate corruptas dicebat. Additit quoque, regem servilibus oculis esse, reginam tria ancillaris ritus officia pre se tulisse».

3. A. Aarne/St. Thompson, The Types of Folktale (Helsinki, 1928, 1961), n: 655 .

4. Many pertinent tales are collected in J. Schick, corpus Hamleticum, I. 4/5 (Leipzig, 1934, 1938). See also A. Ol rik, "Märchen in Saxo Grammaticus», Zeitschrift des Vereins für Volskıonde, 2 (1892), pp. 117-123; F. v. d. Leyen, Die Märchen in den Göttersagen der Edda (Berlin, 1899), pp. 71-79; D. Noy, Folk tales of Israel (Ch icago, 1963), p. 91.

5. In K. Stroebe, Nordische Volksmärchen, I : Dänemark (Jena, $1915)$, n: 39, pp. $168-174$.

6. Cf. M. A. Taylor, A New Look at the Sources of "Hamlet» (The Hague, 1968).

7. Cf. P. Hermann, Erläuterungen zu den ersten neun Büchern der Dänischen Geschich te des Saxo Grammaticus (Leipzig, 1922), 11. 267.

8. St. Thompson, Motif-Index of Folk-Literature, rev. edn. (Copenhagen, 1955-1958), J. 1661.1.1-2.

9. Ibid., F. 647. 5. 1.

10. W. S. Walker/ A. E. Uysal : Tales Alive in Turkey (Cambridge, Mass., 1966), pt. II n 92 , pp. 114-119; H. Stumme, Tun esische Märchen und Gedichte, II (Leibzig, 1893), n. 13, pp. 123-126; A. Wesselski, Marchen des Mitterlalters (Berlin, 1925), n:37, pp. 100-106.

11. F. de Belleforest, Le Cinquiesme tome des Histoires Tragiques, rpt. in I. Gollancz, The Sources of «Hamlet» (London, 1926), p. 236.

12. Ibid., pp. 236-240.

13. Ibid., pp. $242-246$.

14. F. Beaumont and J. Fletcher, Works, ed. A. Waller (1906), IV. 353; Ph. Massinger, Plays and Poems, ed. Ph. Edwards and C. Gibson (1976), III. 423 (I.ii.319). 